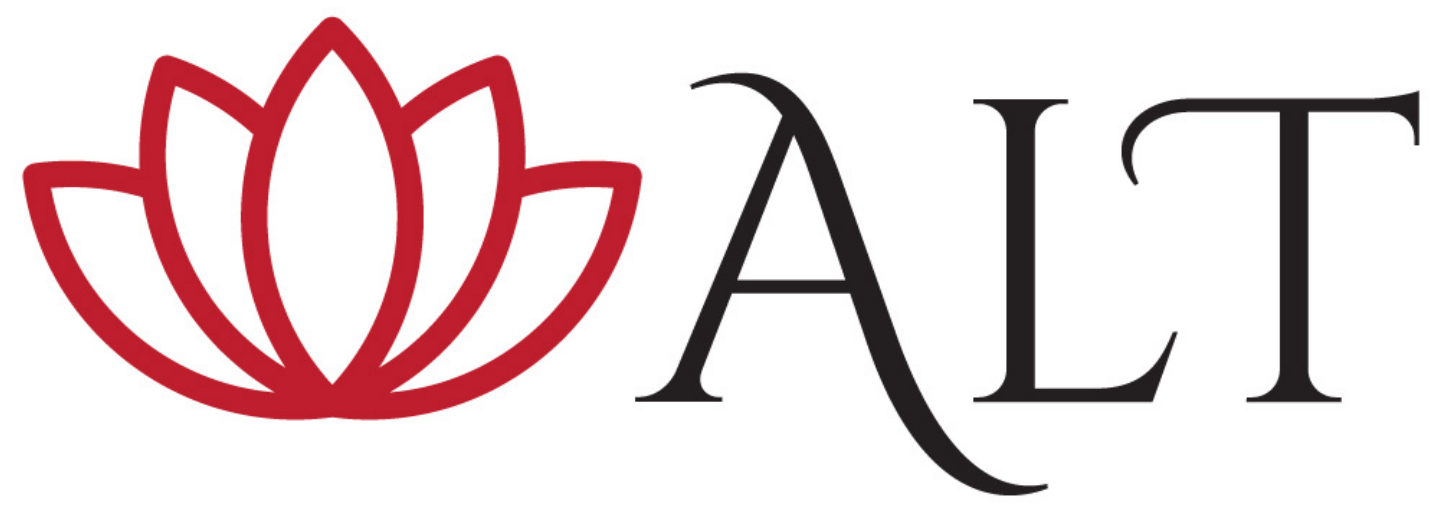

\title{
Asian Literature and Translation
}

ISSN 2051-5863

https://doi.org/10.18573/issn.2051-5863

Vol 4, No. 1, 2017, 96-104

Two Pashto Short Stories

by Abdul Wakil Sulamal Shinwari

Translated by Noorullah Atal

DOI: $\underline{\text { https://doi.org/10.18573/j.2017.10131 }}$

Date Accepted: 01/02/17

This work is licensed under a Creative Commons Attribution-NonCommercial-NoDerivs 4.0 International License (CC-BY-NC-ND) https://creativecommons.org/licenses/by-nc-nd/4.0/

() Noorullah Atal

\section{CARDIFF}

UNIVERSITY

PRIFYSGOL

CAERDYB
Cardiff University Press

Gwasg Prifysgol Caerdydd 
Two Pashto Short Stories

by Abdul Wakil Sulamal Shinwari

Translated by Noorullah Atal 


\section{The Wedding Night}

'Run your hands up inside my sleeves and caress the Kandahari pomegranates within.'

As soon as she sang these words a small grin danced onto her lips, but soon she became

shy and silent. Moments later, many questions tortured her mind: How will he cuddle up to me? How will he kiss me? What will he talk about? What will he say? What if he just manhandles me without asking?

At this point, she laughed. Oh Lord! There are nine buttons on my trousers; it will take him to first prayers to get them undone!

Then another thought occurred to her: Just wait until I add another button!

At this, she slowly added another button to her belt. Once done, she laid down on the white handkerchief her mother-in-law had given her.

To this bride, as with every other Pashtun girl before marriage, such things were simultaneously exciting, scary, and interesting. Since childhood, she had been waiting for this night. For the first time, she would be naked with a grown man.

Feelings of happiness and excitement cast a shadow over her. These feelings, thoughts, and ideas filled the waiting time. Night was closing in but there was still no sign of her husband, to whom she had just handed over control of her body for their pleasure.

Just as fear and doubt were creeping in, her husband slowly entered the room. On seeing him, his bride quickly replaced her veil and remained silent to see how he would initiate the 'bedroom drama' at the beginning of their lifelong journey together. But her husband was still and cold, and lay down lifelessly on the bed. He didn't whisper sweet words into her ear, nor did he excite her by moving his body closer to hers. 
This coldness shocked and worried the young bride. Countless questions, thoughts, and ideas crept into her mind: Maybe he doesn't like me and feels his parents have forced me upon him.

As the hailstorm of such questions rained down in her mind, she had an idea: Jingling your head-bracelet or bangles a little may have an effect on him.

But her husband made no sound or movement in response. He just remained in the same motionless fashion.

Then she thought: Maybe he's argued with someone, or he has exchanged harsh words with his uncle?

Night descended further, and she was at a loss as to what to do to get her husband to react - to kiss her, touch her, compliment her.

Since the bangle-shaking had elicited no response, another idea occurred to her. Move a little closer to him, nudge him with your elbow, get close to him to get him to say something!

But she quickly felt ashamed, shied away, and said to herself: No! He may think of me as a shameless person.

As these worries swamped her, her husband turned onto his side and moved his chest close to her. That movement pleased her a little, but the long yawn that followed immediately wiped it away again. She slowly turned to face him and asked quietly, 'Are you hurt?' Immediately, her husband replied, 'No, sweetheart.'

On hearing him say sweetheart, she was filled with joy, and asked gently, 'Why so glum?' Her husband replied slowly, 'It's nothing ... nothing at all.'

Gently, the woman said: 'It's okay. God will make everything easy, don't worry!'

Her husband let out a long sigh and said: 'Why shouldn't I be hurting? Why shouldn't I be worried?'

His wife was surprised. 'Why, what's wrong?' 
Quietly and in a sad tone, her husband muttered to himself. 'How to make you understand? ... Which words to use?'

But his wife heard and was only more surprised. 'Don't you like me? It's true that I am not worthy of you. You're as tall as a poplar and I'm small and chubby ... How can we be matched? But what can we do? God has brought us together, what can anyone say to that?'

Calmly, her husband said: 'No, sweetie, it is I who am not worthy of you. No one is as beautiful as you; no one can match you. It is as if God has drawn you with his own fair pen.'

'In that case, how come your heart has grown tired of me already? You made me wait for you all evening. What will people say?'

'My heart has not grown tired of you; my heart is tired of me and of the world.'

His wife was still shocked, but her curiosity grew. 'Why are you talking such rubbish? Please just tell me what's wrong.'

This time her husband was on the verge of tears. 'I'm impotent. And I don't know how to make you understand.'

His wife was starting to panic. 'Impotent?'

Her husband couldn't wait any longer. He shot up and reached for the buttons on his belt. His wife was shocked. She was afraid that her husband might have lost his mind.

Now terrified, she asked him: 'What are you doing? What's got into you?'

But her husband slowly replied, 'I'm showing you my deficiency.'

With that, he quickly undid the buttons and let his trousers drop. 'Look! Can you see a difference between me and you? How can I ever get close to you?'

The bride dropped on the bed face-down, not making a sound. But her husband cried, ‘That's why I've always avoided women! ... But what could I have done? How could I have saved my father's honour in the village and society?' 
The bride, screaming: 'So you made me the victim of this, you cruel man ... You monster!' Her husband ran to the corner of the room, took a large knife from the wardrobe, and turned to his wife. 'Slash my throat! I deserve it. God made me this way.'

With tear-filled eyes, the bride replied: 'How will your death ease my pain? You have no brother that I can marry after your death.' 


\section{The Solution}

As soon as Gulalay entered the minister's office she started sobbing and complaining: 'What else should I do? You asked me to become a member of the Democratic Youth Association, so I did. I never missed a meeting. In each meeting I did a lot of hard work. I have even thrown myself into your arms. After all that, I am still being punished.'

The minister was taken aback somewhat, but quickly jumped in: 'Wait, wait! What are you talking about, punishment? Punishment for what? No one would dare to punish you! Just yesterday, I sent a request to the secretary at the Vanguard Association Headquarters to enlist you for a probationary membership in the party.'

He thought for a second and then asked in bewilderment: 'Why? Has someone said something to you? What's the matter?'

Gulalay replied: 'Last night they came to the house and took my father away.'

Shocked, the minister asked: 'Who? The anti-revolutionary elements, or our security comrades?'

Gulalay started crying again. 'Security personnel.'

The minister became slightly pensive, but was quick to console Gulalay: 'Don't panic; if your father is not a criminal, he will be released.'

Then he launched into a series of questions. 'Where did you father study?'

'In America.'

The minister did not like America being mentioned. 'America, America! This America is the nest of imperialism.'

Gulalay was quick to interject: 'But in that nest, the Revolutionary Council, the Main Party Secretary, and the Prime Minister flapped their wings too.' 
The minister smiled. 'You are correct, but they had their reservations against that country and its imperialist ideals even before going to that America. As you are no doubt aware, comrade Gus Hall is also American, as was Martin Luther King; but they are still antiimperialists. The other issue is that there is a big difference between your father and the leader of the Revolutionary Council, my dear!'

Gulalay was surprised. 'In what way?'

The minister replied: 'Your father is from a middle-class landowning family, whereas our party leader is, as you know, the son of a poor shepherd.'

Gulalay interrupted him: 'Minister, sir! No matter which class my father was fated to be connected with, he has never said a single bad word against the revolution.'

The minister said: 'I know. But there must be something.'

Gulalay asked: 'And what is that?'

The minister said: 'He is socialising with anti-revolutionary groups. There are many Maoists; members of the Muslim Brotherhood; Setamis, and Parcham members, and members of the Afghan Millat.'

Gulalay intervened: 'This has got nothing to do with people's political affiliation. You can't abandon your social life just for that.'

The minister laughed. 'That is precisely the issue. Sometimes one rotten apple spoils whole bunch. Why does no one other than revolutionary comrades befriend me?'

Gulalay was perplexed. 'Does that mean that being in contact with people upholding a different ideology is a sin?'

The minister said: 'No, I'm not saying that. I am sure your father knew someone who must have been involved in a plot against the revolution. They must have been caught, and their affiliates exposed.' 
Gulalay sobbed: 'So what is the solution?'

The minister thought for a minute, then said: 'A solution must be found, right? Our security and military comrades are quite emotional! We need to hurry to save his life before they kill him.'

Gulalay started sobbing again, but the minister consoled her: 'Don't cry. Crying won't solve anything - we need to find a solution!'

Emotions overwhelmed Gulalay again: 'But I am a member of the Youth Association, and you have recommended me for a party membership! Is that not enough? What else should I do?'

'I could go to the head of the Revolutionary Council myself on your behalf, and tell the national security head about the issue; but I would have to show them that we have a very close relationship before they would consider my bid for his release.'

Gulalay was shocked. 'Working for you in the ministry; my love for you; the Democratic Youth Association; and lately, my membership of the party - is all that so paltry?'

The minister replied: 'It is good enough for me, but not for them.'

Surprised, Gulalay asked: 'What more do they want?'

The minister said: 'A strong relationship between you, your father and me.'

Gulalay still didn't grasp what the minister was trying to say. 'A strong tie?'

'Meaning, I should tell them that he's my paternal or maternal uncle, or ...'

Gulalay interruped him: 'Or ... !?'

'Or my father-in-law. He clearly can't "become” my uncle - to tell such a lie in front of the party leader would be very immoral.'

Gulalay said: 'Meaning I should marry you?'

The minister smiled. 'We have no other choice.' 
'But you are already married!'

'To hell with her!'

'What will you do with her? I can't live with her under the same roof!'

'It's not a problem, honey; I will send her to her father's. I'll take financial responsibility for her, and I will tell you this minute for certain that I'll never see her face again. I am a victim of feudalism. The revolution has handed me the opportunity to make my own choices, so why should I let it slip away?'

Gulalay said quickly: 'I would die for my father.'

The minister laughed. 'And I would make any sacrifice, and pull any strings I can, for your sake.'

Gulalay said: 'When should this happen?'

The minister said: 'As soon as possible, lest our revolutionary friends implement their revolutionary duty.'

Gulalay was quick to interrupt: 'Very well. If it is okay with you, you can take care of it as soon as tomorrow.'

'No, get yourself ready for a wedding next week; and tomorrow I will go to the party leadership and tell them that your father is to be released as soon as possible!' 